Check for updates

Cite this: RSC Adv., 2017, 7, 37474

Received 18th July 2017

Accepted 21st July 2017

DOI: $10.1039 / \mathrm{c} 7 \mathrm{ra07915j}$

rsc.li/rsc-advances

\section{Facile synthesis of novel hybrid POSS biomolecules via "Click" reactions $\uparrow$}

\author{
Youssef El Aziz, ${ }^{* a}$ Nazia Mehrban, ${ }^{\text {b }}$ Peter G. Taylor, (D) a Martin A. Birchall, ${ }^{\text {b }}$ \\ James Bowen, (DD a Alan R. Bassindale, ${ }^{a}$ Mateusz B. Pitak ${ }^{c}$ and Simon J. Coles (iD) ${ }^{c}$
}

A novel alkyne-terminated cubic-octameric POSS was synthesised in high yield (82-90\%). The X-ray crystal structure revealed intra- and intermolecular hydrogen bonding between the amide groups of the arms. Hybrid biomaterials were synthesised in nearly quantitative yields via a click reaction with (i) azido- $N$ Fmoc-norleucine and (ii) $3^{\prime}$-azido- $3^{\prime}$-deoxythymidine.
Among the most commonly studied scaffolds for developing hybrid biomaterials ${ }^{1-4}$ is polyhedral oligomeric silsesquioxane (POSS). POSS units are symmetrical, three-dimensional cubic molecules, which are unique nanometer-sized hybrid inorganicorganic materials ${ }^{5,6}$ with the formula $\left(\mathrm{RSiO}_{3 / 2}\right)_{8}$, known as $\mathrm{T}_{8}$. POSS contains an inorganic inner siloxane nanocore, with the possibility of chemical functionalisation at each of the eight corners of the cubic unit. POSS units have been used extensively as scaffolds for the development of liquid crystals, ${ }^{7,8}$ biocompatible materials, ${ }^{9}$ catalysts ${ }^{10,11}$ and dendrimers ${ }^{12}$ and can also be used in cross-linking polymers. ${ }^{13}$ Functionalisation of $\mathrm{T}_{8}$ with different substituents has usually been achieved by hydrosilylation, ${ }^{14,15}$ Heck, ${ }^{16-18}$ and cross-metathesis ${ }^{16,19}$ reactions.

Copper-catalyzed Azide-Alkyne Cycloaddition (CuAAC), ${ }^{20,21}$ 'click' chemistry, is a simple method for coupling organic molecules containing azide and alkyne functional groups in high yields and its use in the fields of peptide and protein biomedical and material sciences is accelerating..22,23 The click reaction has been used to synthesise POSS biomaterials such as hybrid POSS-PEG hydrogels ${ }^{24}$ that support chondrocyte attachment and proliferation. Only one synthetic approach towards peptidyl silsesquioxanes using click chemistry has been reported to date. ${ }^{25-30}$ focussing on the synthesis of octa(3azidopropyl)polyhedral oligomeric silsesquioxane POSS- $\left(N_{3}\right)_{8}$ (Fig. 1) and its reaction with a variety of alkynes. ${ }^{25-36}$ The

${ }^{a}$ The Open University, Faculty of Science, Technology, Engineering \& Mathematics, Walton Hall, Milton Keynes, MK7 6AA, UK. E-mail: youssef.elaziz@open.ac.uk; Fax: +44 (0)1908 858327

${ }^{b}$ University College London, Ear Institute, Brain Sciences, 332 Gray's Inn Rd, London WC1X 8EE, UK

'UK National Crystallography Service, Chemistry, University of Southampton, Highfield, Southampton, SO17 1BJ, UK

$\dagger$ Electronic supplementary information (ESI) available: Detailed experimental procedures, ${ }^{1} \mathrm{H},{ }^{13} \mathrm{C},{ }^{19} \mathrm{~F},{ }^{29} \mathrm{Si}$ NMR, IR, MALDI-TOF MS, elemental analysis, and analytical data for all new compounds. For ESI and crystallographic data in CIF or other electronic format. CCDC 1514595. For ESI and crystallographic data in CIF or other electronic format see DOI: $10.1039 / \mathrm{c} 7 \mathrm{ra} 07915 \mathrm{j}$ preparation of octa(3-azidopropyl)polyhedral oligomeric silsesquioxane POSS- $\left(N_{3}\right)_{8}$ requires a multi-step synthesis and suffers from a poor overall yield of $30-32 \% .^{32}$

The synthesis and click reaction of mono alkyneheptaisobutyl POSS were first reported by Müller et al..$^{37}$ and Wu et al..$^{38}$ Müller et al. ${ }^{37}$ have used aminopropylheptaisobutyl polyhedral oligomeric silsesquioxane (POSS) to produce monoalkyne-POSS in three steps and the click coupling occurred between the azido-terminated polystyrenes and alkyne-POSS to afford mono-, di-, and pentafunctional POSS-containing hybrid polystyrenes as star-shaped telechelic POSS-containing hybrid polymers. Wu et al. ${ }^{38}$ have prepared alkyne-functionalized-POSS in three steps from allyl-heptaisobutyl substituted-POSS and the product was linked to an azido-functionalized elastomer of poly(styrene- $b$-(ethylene-co-butylene)- $b$-styrene) $\left(\mathrm{SEB}-\mathrm{CH}_{2} \mathrm{~N}_{3}\right)$ via a click coupling reaction to form a novel hybrid copolymer. These approaches focused mostly on the preparation of a hybrid copolymer based on mono-alkyne-heptaisobutyl and azido polystyrene. However, the preparation of octa-alkyne-terminated POSS and their click coupling reactions with azido-biomolecules to produce hybrid biomaterials has not been investigated yet. We believe that this approach will open a wide range of biomedical applications that were not accessible in the past.

Herein we report a novel synthetic approach to hybrid biomaterials based on octa-alkyne-terminated POSS and their reaction with (i) azido- $N$-Fmoc-L-norleucine and (ii) $3^{\prime}$-azido- $3^{\prime}$ deoxythymidine, using the CuAAC reaction. Our approach

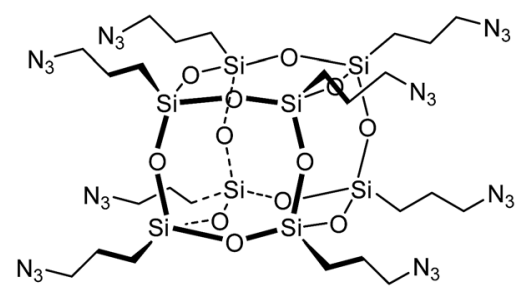

Fig. 1 Octa(3-azidopropyl)POSS. 


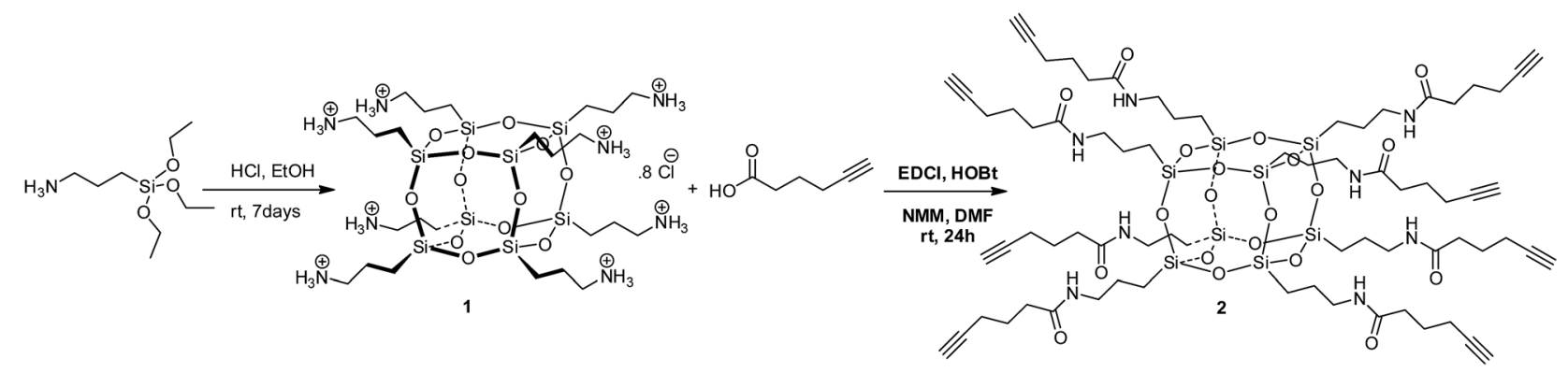

Scheme 1 Synthesis of octa-alkyne-terminated POSS (2).
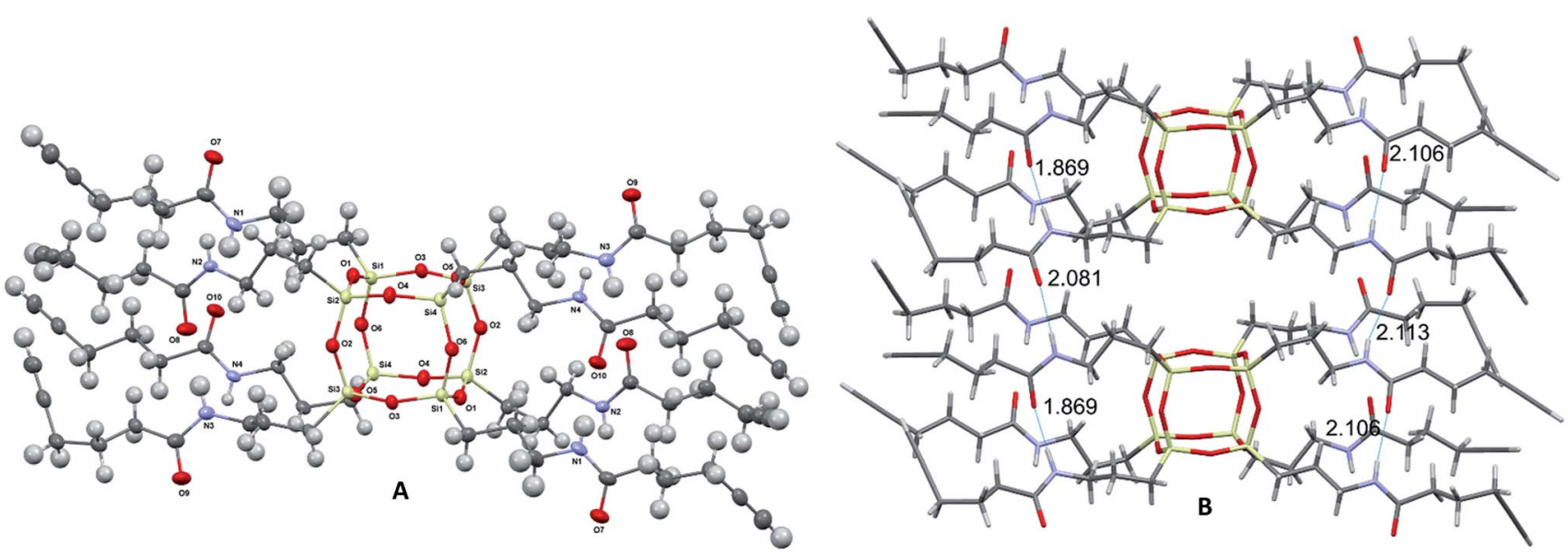

Fig. 2 Molecular structure of 2 grown fragment (thermal ellipsoids drawn with 50\% probability) (A) and the font intra- and inter- $\mathrm{H}$-bonding distances (B).

presents a particularly versatile route which provides a facile and convenient way to functionalise a cubic silsesquioxane core with biomolecules that are more readily available as their azido derivative than their alkyne derivative.

Compound 2 was prepared in one step from commercially available materials; octa(3-aminopropyl)octasilsesquioxane (1) and 5-hexynoic acid (Scheme 1), in 82-90\% yield. Product 2 was isolated and purified by column chromatography, followed by characterisation using standard techniques (see ESI $\dagger$ ). The crystal structure determined by X-ray crystallography (Fig. 2) suggests that intra- and inter-molecular hydrogen bonding between the arms were a fundamental driving force for the formation of a well-defined crystal structure. $\$$

The length of intramolecular nitrogen-hydrogen $(\mathrm{N} \cdots \mathrm{H})$ bonds varies between 2.09(3) and 2.12(3) $\AA$, whereas for an intermolecular bond the distance is 1.87(3) $\AA$.

The completion of the cycloaddition reaction was confirmed by MALDI-TOF and the reaction progress was monitored by

\$ Crystal data of compound 2: $\mathrm{C}_{72} \mathrm{H}_{112} \mathrm{~N}_{8} \mathrm{O}_{20} \mathrm{Si}_{8}\left(M=1634.41 \mathrm{~g} \mathrm{~mol}^{-1}\right)$ : triclinic, space group $P \overline{1}$ (no. 2), $a=9.6202(3) \AA, b=14.1254$ (3) $\AA$, $c=17.6565(6) \AA, \alpha=$ $71.392(2)^{\circ}, \beta=74.675(3)^{\circ}, \gamma=70.560(2)^{\circ}, V=2110.47(12) \AA^{3}, Z=1, T=100.15$ $\mathrm{K}, \mu(\mathrm{Mo} \mathrm{K} \alpha)=0.198 \mathrm{~mm}^{-1}, D_{\text {calc }}=1.286 \mathrm{~g} \mathrm{~cm}^{-3}, 28211$ reflections measured $\left(6.088^{\circ} \leq 2 \Theta \leq 50.054^{\circ}\right), 7434$ unique $\left(R_{\text {int }}=0.0375, R_{\text {sigma }}=0.0368\right)$ which were used in all calculations. The final $R_{1}$ was $0.0459(I>2 \sigma(I))$ and $\mathrm{w} R_{2}$ was 0.1280 (all data). observing the disappearance of the azide asymmetric stretch at $2093 \mathrm{~cm}^{-1}$ and the triple bond $\mathrm{C} \equiv \mathrm{C}$ asymmetric stretch of $\mathrm{T}_{8^{-}}$ [propylhex-5-ynamide] $]_{8}$ (2) at $2100 \mathrm{~cm}^{-1}$ by FT-IR spectroscopy together with monitoring the disappearance in the ${ }^{13} \mathrm{C}-\mathrm{NMR}$ spectrum of the two peaks (89.20 and $76.56 \mathrm{ppm}$ ) representing the triple bond of 2.

Compounds $\mathbf{3}$ and $\mathbf{4}$ have been analysed and characterised using NMR $\left({ }^{1} \mathrm{H},{ }^{13} \mathrm{C}\right.$ and $\left.{ }^{29} \mathrm{Si}\right)$ spectroscopy, infrared and MALDI-TOF mass spectrometry in positive ion mode with a DHB matrix.

Trastoy et $a l .^{32}$ have reported an efficient preparation of highly functionalised cubic-octameric POSS frameworks by click chemistry and the highest yield $(96 \%)$ was obtained with the $\mathrm{CuSO}_{4} \cdot \mathrm{H}_{2} \mathrm{O}$ /sodium ascorbate precatalyst system ${ }^{20}$ using a biphasic organic solvent/water mixture at room temperature for 24 hours. We have used these reaction conditions for the functionalisation of the octa-alkyne-terminated POSS with azido- $N$-Fmoc-norleucine and $3^{\prime}$-azido- $3^{\prime}$-deoxythymidine (Scheme 2).

The MALDI-TOF MS of compound 3 and 4 revealed that the octa-alkyne-terminated POSS has been fully functionalised with azido- $N$-Fmoc-norleucine for 3 and $3^{\prime}$-azido- $3^{\prime}$-deoxythymidine for 4. The molecular ion peak of 3 observed at found $4787 \mathrm{Da}$ is attributed to $[\mathrm{M}+\mathrm{H}]^{+}$and $\mathbf{4}$ observed at $3835.3 \mathrm{Da}$ is attributed to $[\mathrm{M}+\mathrm{Cu}]^{+}$. 


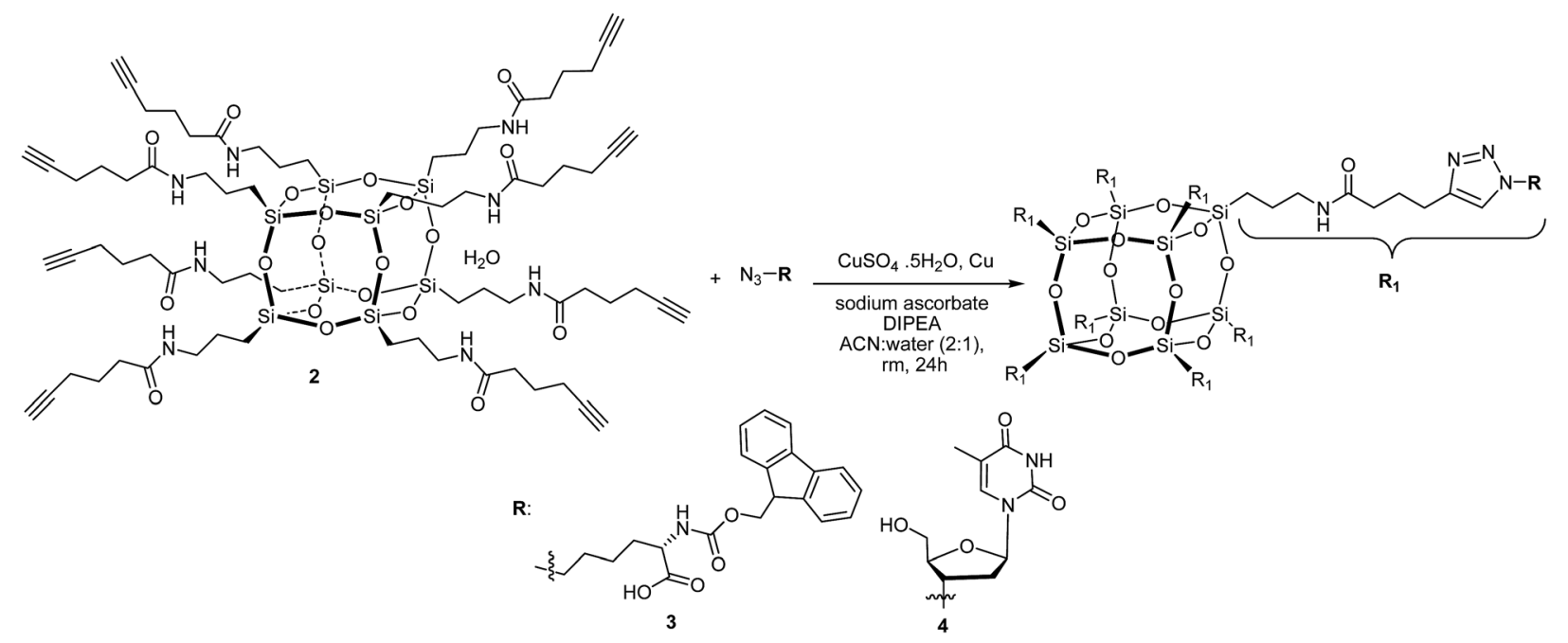

Scheme 2 Synthesis of 3 and 4 using CuAAC approach.

\section{Conclusions}

In this study we have described a novel, efficient method for the synthesis of 3D radially symmetrical biomolecule-POSS hybrids. We have developed a one-step synthesis of 2 from commercially available octakis(3-aminopropyl)octa-silsesquioxane (1) with high yield (82-90\%). The X-ray crystal structure shows that compound 2 exhibits plane-to-plane stacking with an intra- and inter-molecular hydrogen bond network. The octa-alkyneterminated POSS was efficiently and regioselectively octafunctionalised with two azido-R species (where R are Fmoc-Leu and thymidine) by copper(I)-catalysed 1,3-dipolar azide-alkyne cycloaddition (CuAAC) under biphasic conditions. This led to new hybrid biofunctional nanocages 3 and $\mathbf{4}$ in high yield. This new strategy of functionalisation of terminated alkyne-POSS via CuAAC opens many possibilities for the efficient and controlled assembly of new hybrid biomaterials with a high degree of symmetry and with carefully tailored functional properties.

\section{Acknowledgements}

We thank the EPSRC National Mass Spectrometry Service Centre (NMSSC) at Swansea and MEDAC Ltd. of Brunel University for elemental analysis. We thank the EPSRC UK National Crystallography Service at the University of Southampton for the collection of the crystallographic data.

\section{Notes and references}

1 S. Fabritz, S. Horner, O. Avrutina and H. Kolmar, Org. Biomol. Chem., 2013, 11, 2224-2236.

2 C. P. Teng, K. Y. Mya, K. Y. Win, C. C. Yeo, M. Low, C. He and M.-Y. Han, NPG Asia Mater., 2014, 6, e142.

3 Y.-C. Lin and S.-W. Kuo, J. Polym. Sci., Part A: Polym. Chem., 2011, 49, 2127-2137.

4 H. Ghanbari, B. G. Cousins and A. M. Seifalian, Macromol. Rapid Commun., 2011, 32, 1032-1046.
5 D. B. Cordes, P. D. Lickiss and F. Rataboul, Chem. Rev., 2010, 110, 2081-2173.

6 P. D. Lickiss and F. Rataboul, in Adv. Organomet. Chem., ed. F. H. Anthony and J. F. Mark, Academic Press, 2008, vol. 57, pp. 1-116.

7 I. M. Saez and J. W. Goodby, Liq. Cryst., 1999, 26, 1101-1105. 8 Elsa, G. H. Mehl, J. W. Goodby and D. J. Photinos, Chem. Commun., 2000, 851-852.

9 F. J. Feher, K. D. Wyndham and M. A. Scialdone, Chem. Commun., 1998, 1469-1470.

10 L. A. Bivona, O. Fichera, L. Fusaro, F. Giacalone, M. BuakiSogo, M. Gruttadauria and C. Aprile, Catal. Sci. Technol., 2015, 5, 5000-5007.

11 C.-H. Lu and F.-C. Chang, ACS Catal., 2011, 1, 481-488.

12 I. M. Saez, J. W. Goodby and R. M. Richardson, Chem.-Eur. J., 2001, 7, 2758-2764.

13 I. A. Zucchi, M. J. Galante and R. J. J. Williams, Eur. Polym. J., 2009, 45, 325-331.

14 L. Zheng, R. J. Farris and E. B. Coughlin, Macromolecules, 2001, 34, 8034-8039.

15 M. F. Roll, M. Z. Asuncion, J. Kampf and R. M. Laine, ACS Nano, 2008, 2, 320-326.

16 G. Cheng, N. R. Vautravers, R. E. Morris and D. J. ColeHamilton, Org. Biomol. Chem., 2008, 6, 4662-4667.

17 C. M. Brick, R. Tamaki, S. G. Kim, M. Z. Asuncion, M. Roll, T. Nemoto, Y. Ouchi, Y. Chujo and R. M. Laine, Macromolecules, 2005, 38, 4655-4660.

18 A. Sellinger, R. Tamaki, R. M. Laine, K. Ueno, H. Tanabe, E. Williams and G. E. Jabbour, Chem. Commun., 2005, 3700-3702.

19 S. Sulaiman, A. Bhaskar, J. Zhang, R. Guda, T. Goodson and R. M. Laine, Chem. Mater., 2008, 20, 5563-5573.

20 V. V. Rostovtsev, L. G. Green, V. V. Fokin and K. B. Sharpless, Angew. Chem., Int. Ed., 2002, 41, 2596-2599.

21 C. W. Tornøe, C. Christensen and M. Meldal, J. Org. Chem., 2002, 67, 3057-3064. 
22 K. Nwe and M. W. Brechbiel, Cancer Biother. Radiopharm., 2009, 24, 289-302.

23 J.-F. Lutz and Z. Zarafshani, Adv. Drug Delivery Rev., 2008, 60, 958-970.

24 X. Pan, H. Gao, G. Fu, Y. Gao and W. Zhang, RSC Adv., 2016, 6, 23471-23478.

25 Z. Wang, Y. Li, X.-H. Dong, X. Yu, K. Guo, H. Su, K. Yue, C. Wesdemiotis, S. Z. D. Cheng and W.-B. Zhang, Chem. Sci., 2013, 4, 1345-1352.

26 H. Su, J. Zheng, Z. Wang, F. Lin, X. Feng, X.-H. Dong, M. L. Becker, S. Z. D. Cheng, W.-B. Zhang and Y. Li, ACS Macro Lett., 2013, 2, 645-650.

27 H. B. Tinmaz, I. Arslan and M. A. Tasdelen, J. Polym. Sci., Part A: Polym. Chem., 2015, 53, 1687-1695.

28 B. Trastoy, D. A. Bonsor, M. E. Pérez-Ojeda, M. L. Jimeno, A. Méndez-Ardoy, J. M. García Fernández, E. J. Sundberg and J. L. Chiara, Adv. Funct. Mater., 2012, 22, 3191-3201.

29 X. Feng, S. Zhu, K. Yue, H. Su, K. Guo, C. Wesdemiotis, W.-B. Zhang, S. Z. D. Cheng and Y. Li, ACS Macro Lett., 2014, 3, 900-905.
30 S. Fabritz, D. Heyl, V. Bagutski, M. Empting, E. Rikowski, H. Frauendorf, I. Balog, W.-D. Fessner, J. J. Schneider, O. Avrutina and H. Kolmar, Org. Biomol. Chem., 2010, 8, 2212-2218.

31 G. M. Ziarani, M. S. Nahad, N. Lashgari and A. Badiei, Acta Chim. Slov., 2015, 62, 709-715.

32 B. Trastoy, M. E. Pérez-Ojeda, R. Sastre and J. L. Chiara, Chem.-Eur. J., 2010, 16, 3833-3841.

33 V. Ervithayasuporn, X. Wang and Y. Kawakami, Chem. Commun., 2009, 5130-5132.

34 Z. Ge, D. Wang, Y. Zhou, H. Liu and S. Liu, Macromolecules, 2009, 42, 2903-2910.

35 A. Blazquez-Moraleja, M. Eugenia Perez-Ojeda, J. R. Suarez, M. Luisa Jimeno and J. L. Chiara, Chem. Commun., 2016, 52, 5792-5795.

36 W. Zhang and A. H. E. Müller, Polymer, 2010, 51, 2133-2139. 37 W. Zhang and A. H. E. Müller, Macromolecules, 2010, 43, 3148-3152.

38 M. Niu, R. Xu, P. Dai and Y. Wu, Polymer, 2013, 54, 26582667. 